\title{
Post-emergent applications of isolated and combined herbicides on corn culture with cp4-epsps and pat genes
}

\author{
Fabio Henrique Krenchinski ${ }^{\mathrm{a}}$, Alfredo Júnior Paiola Albrecht ${ }^{\mathrm{b}}$, Victor José Salomão Cesco ${ }^{\mathrm{a}, *}$, \\ Danilo Morilha Rodrigues ${ }^{\mathrm{a}}$, Vinicius Gabriel Caneppele Pereira ${ }^{\mathrm{a}}$, Leandro Paiola Albrecht ${ }^{\mathrm{b}}$, \\ Caio Antonio Carbonari ${ }^{\mathrm{a}}$, Ricardo Victória Filho ${ }^{\mathrm{c}}$
}

${ }^{\text {a }}$ São Paulo State University (Unesp), School of Agriculture, Botucatu, Brazil

${ }^{\mathrm{b}}$ Federal University of Paraná - Agronomy Department, Palotina, Brazil

${ }^{\mathrm{c}}$ Luiz de Queiroz College of Agriculture, University of São Paulo, Piracicaba, Brazil

\section{A R T I C L E I N F O}

\section{Nomenclature:}

glufosinate-ammonium

atrazine

glyphosate

corn

Zea mays LKeywords:

Association herbicides

Liberty link

Roundup ready

\begin{abstract}
A B S T R A C T
For optimum yield, it is necessary to incorporate a good weed control into the system. This study aimed to determine the effects of a post-emergent application of different herbicides (individually and combined) on corn presenting cp4-epsps and pat genes. Field studies were conducted on the corn hybrid 2 B810 with the cp4-epsps and pat genes in the agricultural years 2012/13 and 2013/14 and included 8 treatments with isolated and combined application of glyphosate, glufosinate-ammonium, and atrazine. The variables evaluated were chlorophyll type a and b, total chlorophyll index, stem diameter, height of the cob insertion, prolificacy index, first height, second height, yield, and volume of 100 grains. The combination of all three herbicides hindered the yield of corn cultures. This practice therefore requires caution when applied to weed management. The combination of two herbicides did not affect the final height or yield and may be a useful method of weed management in future.
\end{abstract}

\section{Introduction}

Corn (Zea mays L.) is considered one of the most important cultivated and consumed cereals worldwide because of its productive potential, chemical composition, and nutritional value (Fancelli and Dourado Neto, 2000). In Brazil, in the agricultural year 2015/16, calculations made for the first and second corn crop showed a national cultivation of 15.756 million hectares, with a mean yield of $4.84 \mathrm{~kg} \mathrm{ha}^{-1}$ and a production of approximately 76 million tons (Conab, 2016).

To gain higher earnings, it is necessary to have adequate weed control because weeds can cause a loss in earnings of 13\%-88\% (Dan et al., 2010). Of all the control methods applied to corn, the chemical method is still the most widely utilized one, with herbicides being used to cultivate corn in an estimated $65 \%$ of the area in Brazil (Karam and Gama, 2008).

To assist the plant in its development and prevent production losses because of weeds, we used the Roundup Ready 2 (RR2 - cp4-epsps gene) strain of corn, which is tolerant of the herbicide glyphosate used in the effective control of many weeds that compete with corn cultures. The RR2 corn is widely cultivated in countries such as the United States,
Canada, Argentina, South Africa, Uruguay, and Columbia (Monsanto, 2016). Liberty Link technology (LL) with phosphinothricin acetyltransferase gene (pat gene) is also used for weed control in a productive system and enables the use of glufosinate-ammonium-based herbicides that can be tolerated by corn plants (Bayer Crop Science, 2016). This is beneficial to the system as fewer machines are necessary, and the rotation of corn cultures is optimized because of the low residue on the ground.

In Brazil the RR2 - cp4-epsps gene technology was approved by CTNBio in 2009 (CTNBio, 2017) but not used for cultivation in commercially significant areas until 2011. There is great potential for this technology once/if accepted by farmers in the coming years as it greatly facilitates weed control. Because of the growing attention that the RR2 cp4-epsps strain of corn has been receiving nationally and worldwide in the last few years, lot of research has been focused on understanding the effects of post-emergent applications of glyphosate herbicides on corn cultures in the classic formulations marketed. In terms of approving technology for genetically modified organisms, the LL - pat gene technology for corn culture was approved by the qualified authorities at the beginning of 2008 for study purposes and commercially in 2013 (Bayer Crop Science, 2016). Glufosinate-ammonium belongs to

\footnotetext{
* Corresponding author.

E-mail address: victorcesco@hotmail.com (V.J. Salomão Cesco).
} 
Table 1

Chemical and physical analysis of the soil from the field in Marechal Cândido Rondon at a soil depth of 0.0-0.20 cm. Marechal Cândido Rondon-PR, 2013

\begin{tabular}{|c|c|c|c|c|c|c|c|c|}
\hline P (Mehlich) & $\mathrm{K}$ & C & $\mathrm{Ca}$ & $\mathrm{Mg}$ & $\mathrm{H}+\mathrm{Al}$ & $\mathrm{pH}\left(\mathrm{CaCl}_{2}\right)$ & $\mathrm{Al}$ & $\mathrm{SB}$ \\
\hline 29.40 & 1.68 & 20.25 & 7.86 & 2.42 & 3.97 & 5.61 & 0.00 & 11.96 \\
\hline $\mathrm{Zn}$ & $\mathrm{Fe}$ & $\mathrm{Mn}$ & $\mathrm{Cu}$ & $\mathrm{V}$ & СTC & Areia & Silte & Argila \\
\hline 7.07 & 19.93 & 67.90 & 16.68 & 75.08 & 15.93 & 17.80 & 19.25 & 62.95 \\
\hline
\end{tabular}

Units: $\mathrm{P}, \mathrm{Cu}, \mathrm{Zn}, \mathrm{Fe}$, and $\mathrm{Mn}\left(\mathrm{mg} \mathrm{dm}{ }^{-3}\right) ; \mathrm{K}, \mathrm{Ca}, \mathrm{Mg}, \mathrm{H}+\mathrm{Al}, \mathrm{Al}, \mathrm{SB}$, and $\mathrm{CTC}\left(\mathrm{cmol}_{\mathrm{c}} \mathrm{dm}^{-3}\right) ; \mathrm{C}\left(\mathrm{g} \mathrm{dm}^{-3}\right)$; V, sand, silt, and clay (\%).

A

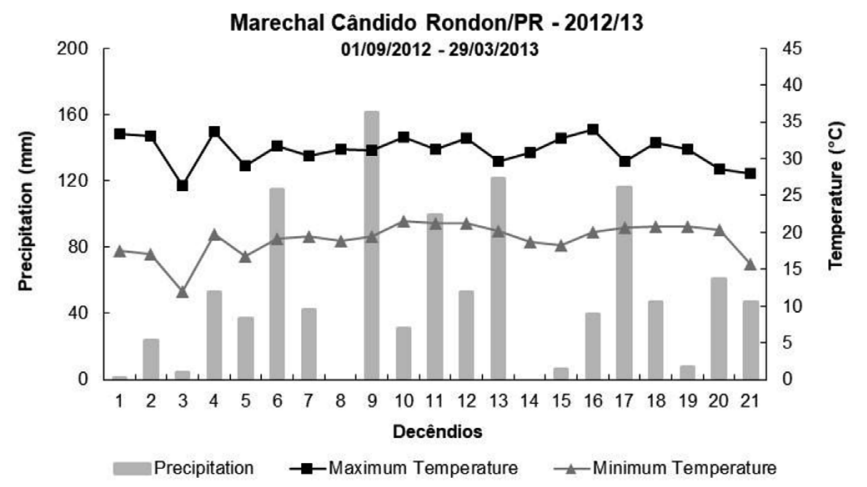

B

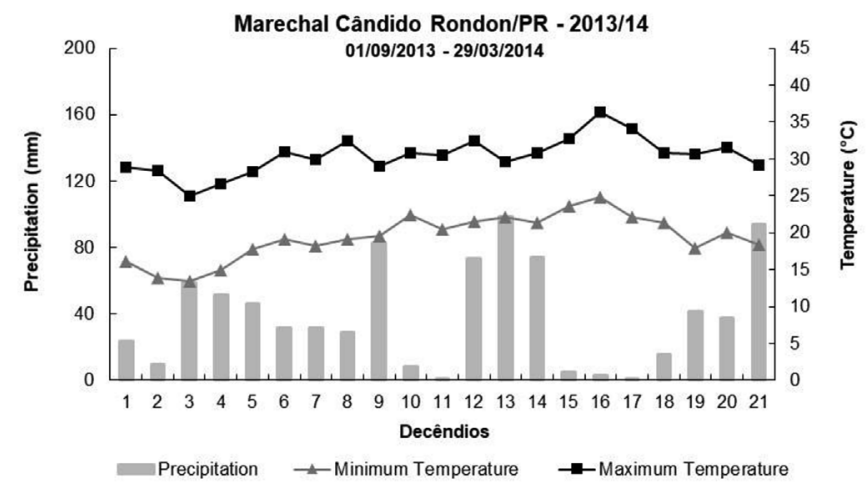

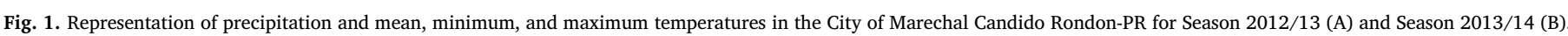
Source: Instituto Nacional de Meteorologia - INMET (2015).

Table 2

Treatments with herbicides applied to corn with the cp4-epsps and pat genes in 2012/2013 and 2013/2014.

\begin{tabular}{|c|c|c|c|}
\hline Treatments & \multicolumn{2}{|l|}{ Herbicides } & Doses g a.e. or a.i. ha ${ }^{-1}$ \\
\hline $\mathrm{T} 1$ & \multicolumn{2}{|l|}{ Control } & 0 \\
\hline $\mathrm{T} 2$ & \multicolumn{2}{|l|}{ Glyphosate } & 1080 \\
\hline Т3 & \multicolumn{2}{|c|}{ Glufosinate-ammonium } & 500 \\
\hline $\mathrm{T} 4$ & \multicolumn{2}{|l|}{ Atrazine } & 2000 \\
\hline T5 & \multicolumn{2}{|c|}{ Glyphosate + glufosinate-ammonium } & $1080+500$ \\
\hline T6 & \multicolumn{2}{|c|}{ Glyphosate + atrazine } & $1080+2000$ \\
\hline $\mathrm{T} 7$ & \multicolumn{2}{|c|}{ Glufosinate-ammonium + atrazine } & $500+2000$ \\
\hline $\mathrm{T} 8$ & \multicolumn{2}{|c|}{ Glyphosate + glufosinate-ammonium + atrazine } & $1080+500+2000$ \\
\hline Herbicides & Trade names & Formulation concentration & Manufacturer \\
\hline Glyphosate & Roundup Ready & $480 \mathrm{~g}_{\text {a.e. }} \mathrm{ha}^{-1}$ & Monsanto Co. \\
\hline Glufosinate-ammonium & Finale & $200 \mathrm{~g}_{\text {a.i. }} \mathrm{ha}^{-1}$ & Bayer Crop Science \\
\hline Atrazine & Primóleo & $400 \mathrm{~g}$ a.i. $\mathrm{ha}^{-1}$ & Syngenta Crop Protection \\
\hline
\end{tabular}

a.e. (acid equivalent) and a.i. (active ingredient).

a class of growth regulating herbicides with post-emergent applications on the weeds found in lettuce, cotton, banana, coffee, citrus, eucalyptus, apple, corn, nectarine, peach, cabbage, soybean, wheat, and grape cultures (Anvisa, 2016).

Because these technologies are usually integrated (RR2 and LL - cp4epsps and pat genes) in a corn hybrid and are recent technologies, studies need to be conducted to determine the production characteristics of other post-emergent herbicide combinations on the cp4-epsps and pat gene strains of corn. Thus, the objective of this study was to evaluate the effects of the post-emergent application of isolated and combined herbicides on corn presenting the cp4-epsps and pat genes.

\section{Materials and methods}

\subsection{Field experiments}

The experiments were conducted on a field in the city of Marechal Cândido Rondon, in the West Region of the State of Paraná, Brazil, in the agricultural years 2012/13 and 2013/14; the altitude of the study site was $285 \mathrm{~m}$ (geographical coordinates: $24^{\circ} 41^{\prime} 52^{\prime \prime} \mathrm{S}$; $54^{\circ} 06^{\prime} 59^{\prime \prime} \mathrm{O}$ ). According to the Köppen classification, the weather in this test area was predominantly Cfa - mesothermal, subtropical, and humid. The characteristics of this type of climate are hot summers, mild winters, and precipitation occurring mainly during the summer season (Iapar, 1987).

Chemical and physical analysis of the soil was performed before the commencement of the experiments (before the first agricultural year) at a depth of $0.00-0.20 \mathrm{~m}$ (Table 1 ). The soil was classified in a previous study as a typical eutroferric Red Oxisol with a very clayish texture (Embrapa, 2013).

The rainfall data and the maximum and minimum temperatures during the experiments were collected daily (Fig. 1A and B).

In total, there were 32 plots and 8 treatments (T1, control; T2, glyphosate; T3, glufosinate-ammonium; T4, atrazine; T5, glyphosate + glufosinate-ammonium; T6, glyphosate + atrazine; T7, glufosinate-ammonium + atrazine; T8, glyphosate + glufosinate-ammonium + atrazine; Table 2$)$. The plots $\left(16 \mathrm{~m}^{2}\right.$ in total) were divided into 


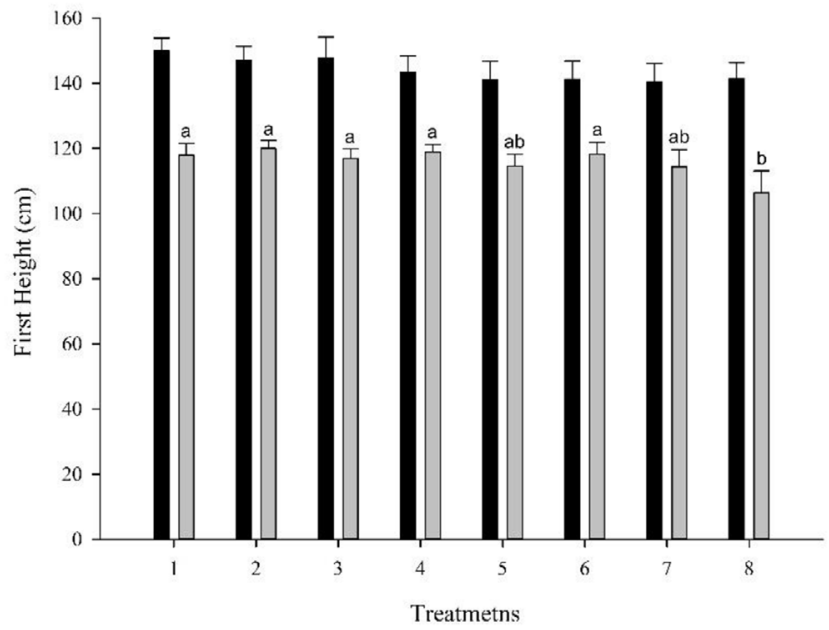

Season 2012/2013
B

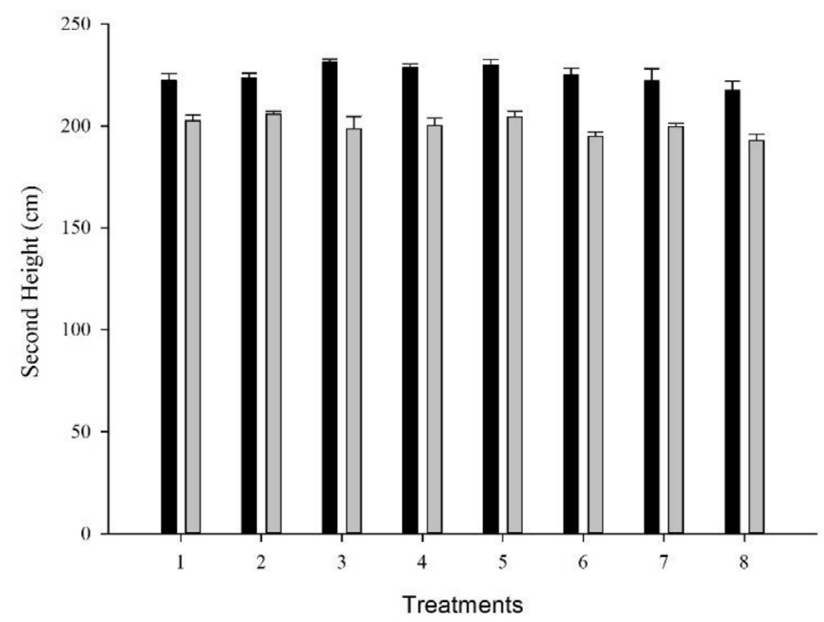

Season 2013/2014

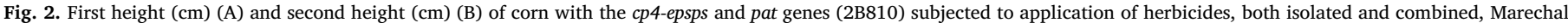

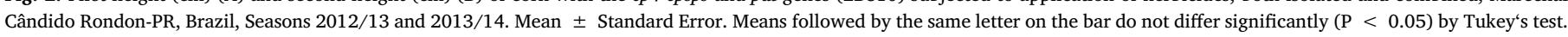

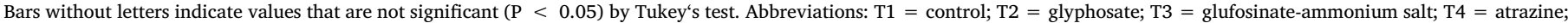

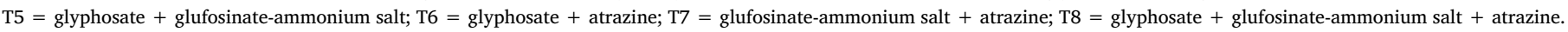

six 6-m-long rows of corn grown $0.45 \mathrm{~m}$ apart. The four central rows ( $9 \mathrm{~m}^{2}$ of the plot), after excluding $0.45 \mathrm{~m}$ on all sides, were considered the useful area of the plot.

For the applications of the treatments, in the V4 phenological estate (Ritchie et al., 2001), a $\mathrm{CO}_{2}$-propelled backpack pulverizer was used with a constant pressure of 2 bar and a flow rate of $0.65 \mathrm{~L} \mathrm{~min}^{-1}$, equipped with a bar containing 6 ends like a fan, XR 110.02 type of the Teejet series. This worked at a height of $50 \mathrm{~cm}$ from the target at a speed of $1 \mathrm{~m} \mathrm{~s}^{-1}$ and reached an applied range of $50 \mathrm{~cm}$ width, which resulted in a syrup volume of $200 \mathrm{~L} \mathrm{ha}^{-1}$.

The dates and average environmental conditions during each application on the Seasons were recorded. For the corn in agricultural year 2012/13, the application was made on 10/24/2012 (relative humidity $(\mathrm{RH})=59 \%$; wind speed (ws) $=3.2 \mathrm{~km} \mathrm{~h}^{-1}$; temperature $\left.(\mathrm{T})=27.3^{\circ} \mathrm{C}\right)$. In $2013 / 14$ Season, the application was made on $10 /$ $29 / 2013\left(\mathrm{RH}=68 \%\right.$; ws $\left.=3.7 \mathrm{~km} \mathrm{~h}^{-1} ; \mathrm{T}=25.4{ }^{\circ} \mathrm{C}\right)$.

The corn hybrid used was the 2B810 PowerCore (in both agricultural years), which is resistant to Lepidoptera but tolerant of both the glyphosate (RR2 - cp4-epsps gene) and glufosinate-ammonium (LL pat gene) herbicides. The fertilizing practices, culture installation, and phytosanitary handlings were conducted according to the Embrapa (2013) recommendations. Manually hoeing the experimental area on a regular basis kept it weed free for the duration of the experiment.

\subsection{Data gathering}

In the $\mathrm{R} 1$ stadium, evaluations on the chlorophyll type $\mathrm{a}$ and $\mathrm{b}$ and total chlorophyll indices were conducted using an electronic chlorophyll measurer (ClorofiLOG). This equipment determines the index of the Falker chlorophyll, which presents high correlation to laboratory analysis of chlorophyll type a and b (Falker, 2009). Standardization was conducted on 10 randomly selected plants in the useful area of the plot, always on the leaf opposite to the cob.

The variables evaluated to determine agronomic performance were stem diameter, height of the cob insertion, prolificacy index, first height, second height, yield, and volume of 100 grains. Among the quoted evaluations, the first height was measured in the V12 state; all of the rest were conducted right after the physiological ripeness of the culture (R6).

For the evaluations of the stem diameter ( $4 \mathrm{~cm}$ above the ground), height of the cob insertion, prolificacy index, first height, and second height, 10 plants from the useful area of the plot were selected at random and measured. The first height was measured as the distance from the surface of the ground to the opening of the shell, while the second height was measured as the distance from the surface of the ground to the insertion of the tassel.

To estimate yield, cobs from the useful area of the plots were harvested manually and placed in the thresher for experiments, cleansed with sifters, and packed in paper bags. Next, the weight of 100 grains was measured four times for each plot. For yield measurements, the humidity of the material collected was corrected to $13 \%$. The quality of the grains was evaluated during the first count of the germination test (strength indicator) and the second count (germination), as described by Brasil (2009).

\subsection{Statistical analyses}

The data was analyzed according to the methods of Pimentel-Gomes and Garcia (2002). Once the basic assumptions for the variance analysis were met, the treatment averages were compared using Tukey's post hoc test $(\mathrm{P}<0.05)$.

\section{Results}

For the two agricultural years (2012/2013 and 2013/2014) at the location where the field experiments were conducted, the weather characteristics presented themselves close to the regional historical average (Fig. 1A and B). The only highlight was that during the second agricultural year (2013/14), there was a small hydrous deficit at the end of the culture cycle, close to the physiological ripeness (Fig. 1B). This demonstrated considerable hydrous and thermal regularity during the realization of the experiments, providing the culture with near-expected development. There was a significant difference between the agricultural years, attributing this factor to the climatic differences 


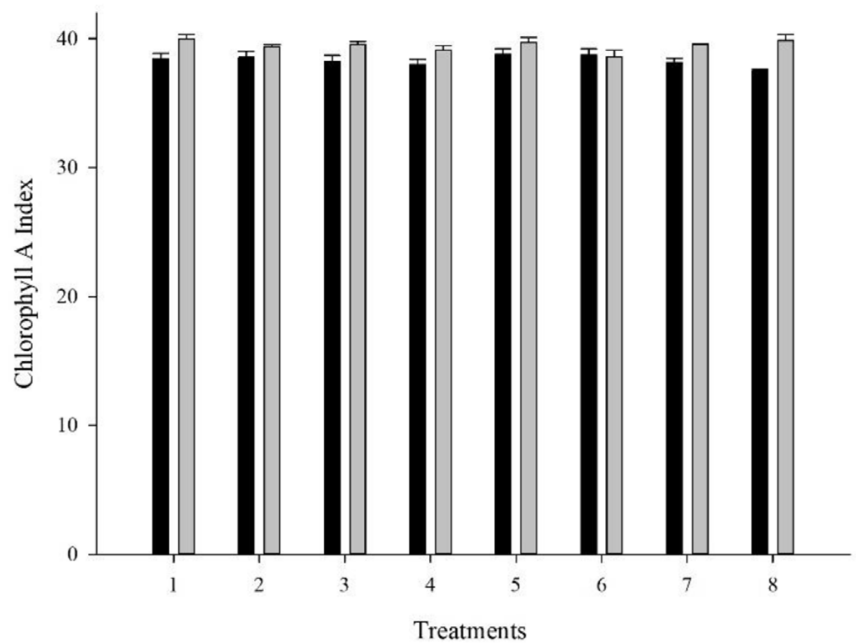

$\mathrm{C}$

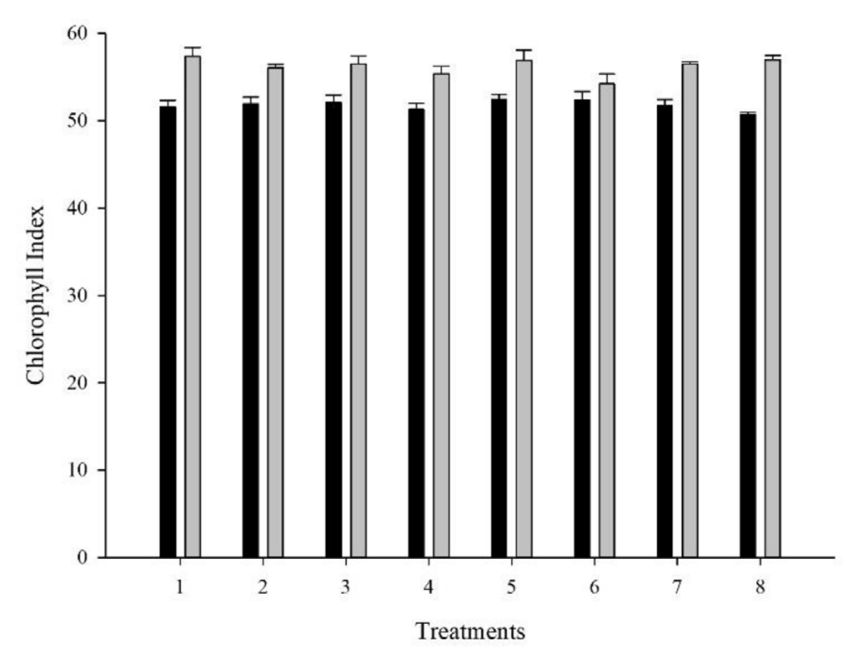

Season 2012/2013

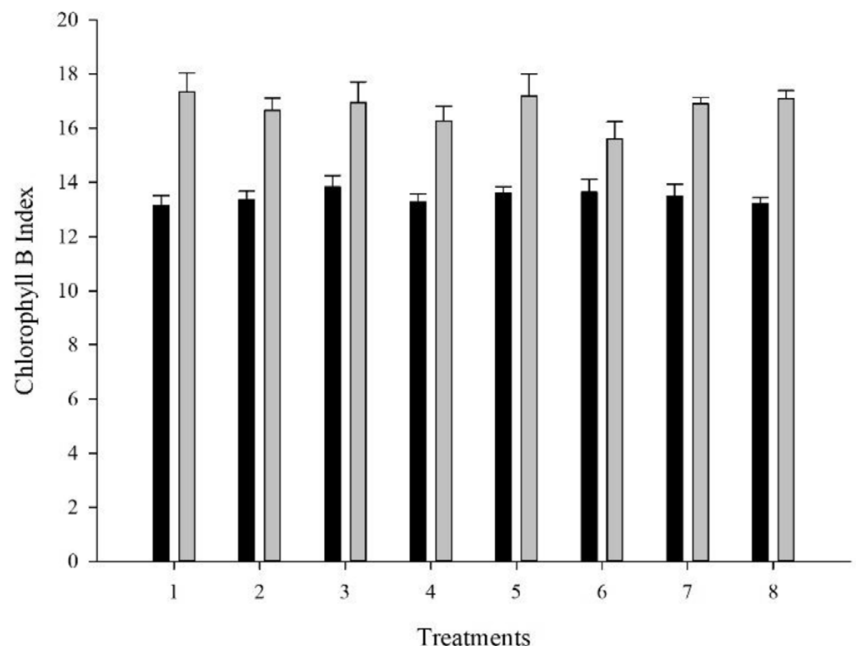

Treatments

Season 2013/2014

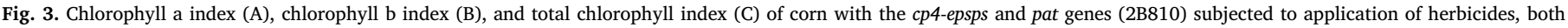

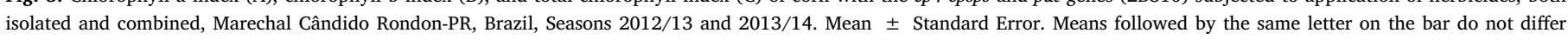

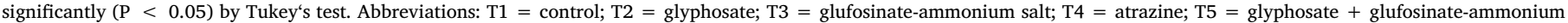
salt; $\mathrm{T} 6=$ glyphosate + atrazine; $\mathrm{T} 7=$ glufosinate-ammonium salt + atrazine; $\mathrm{T} 8=$ glyphosate + glufosinate-ammonium salt + atrazine .

observed, so the data were discussed according to the behavior in each harvest.

In both agricultural years, the first and second height of the corn with the cp4-epsps and pat genes did not improve with the herbicide applications (Fig. 2A and B); however, the first height was affected negatively in Seasons that had the T8 treatment. Similar to previous studies, we found that T6 did not affect the height or production characteristics of the corn culture (Vieira Júnior et al., 2015; Osório et al., 2015). Armel et al. (2008) also found that a combination of the herbicides glufosinate + mesotrione had no significant effect on the final height and dry weight of the plants.

Studies have found that the initial growth of crops can be affected (Albrecht et al., 2017), by the early accumulation of
Aminomethylphosphonic acid (Reddy et al., 2009) in treatments containing glyphosate (e.g., T5 and T8) or by the accumulation of glufosinate-ammonium and acetyl-glufosinate in the first hours following the application (Everman et al., 2009) in treatments containing glufosinateammonium (e.g., T7 and T8). However, we found that T5 and T8, which contained glyphosate and glufosinate-ammonium, respectively, did not affect the initial growth of the crops.

We found no significant difference across all 8 treatments in the chlorophyll indices in R1 for chlorophyll a (Fig. 3A), chlorophyll b (Fig. 3B), and total chlorophyll (Fig. 3C) indices on the corn in both agricultural years. Thus, the type and combination of herbicides had no effect on the chlorophyll indices of the corn cultures. Similarly, when evaluating the color green index in RR corn cultures, Osório et al. 
A

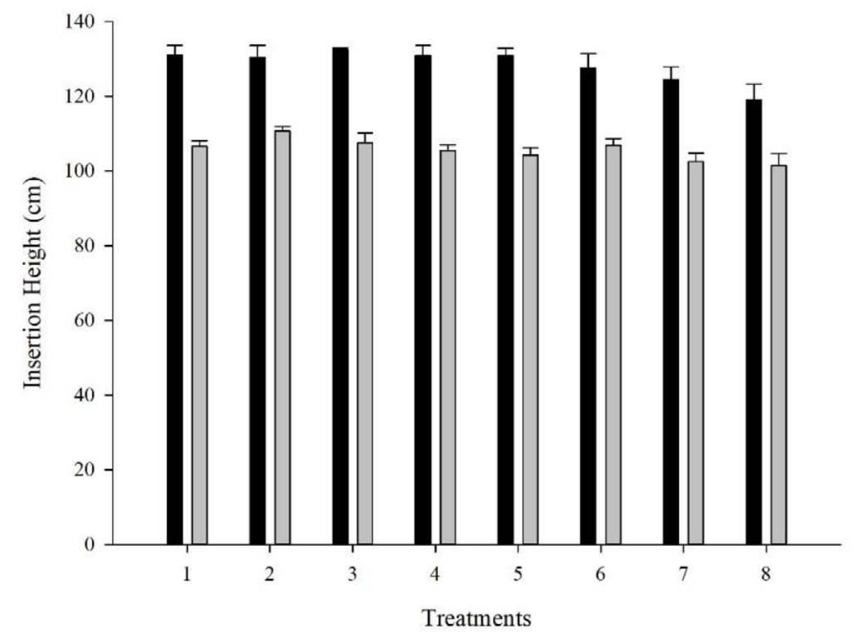

C

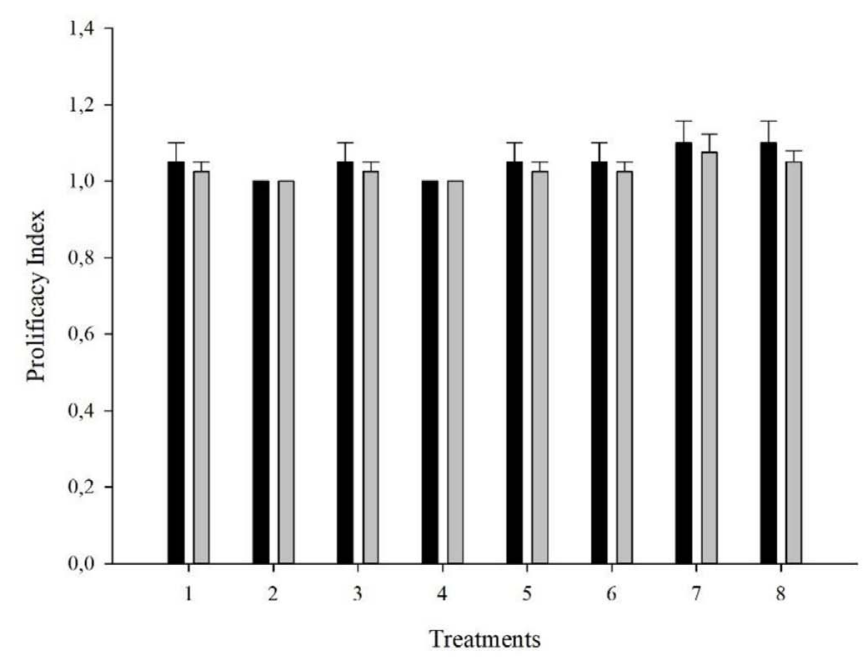

B

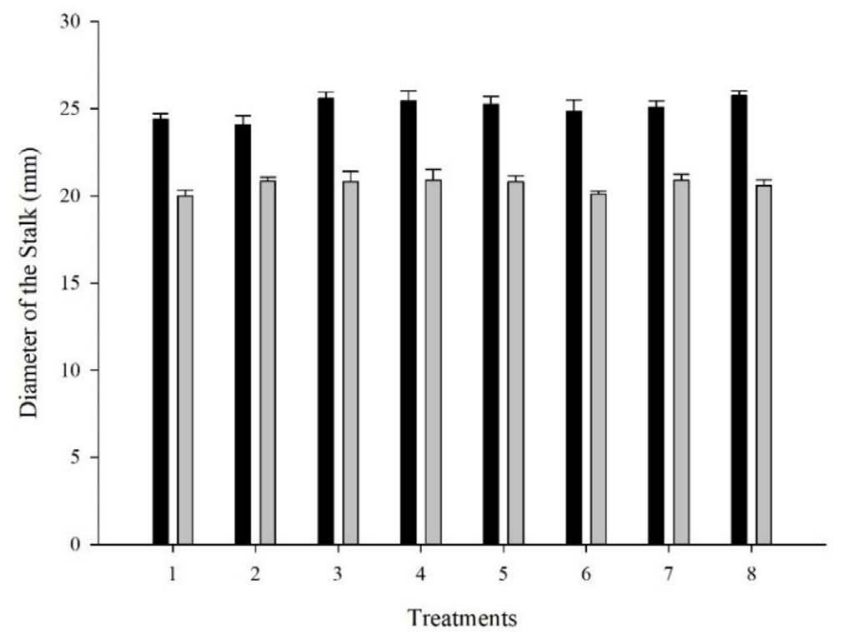

Season 2012/2013

Season 2013/2014

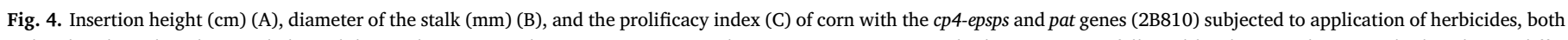

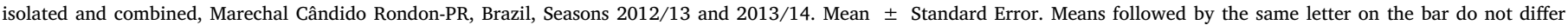

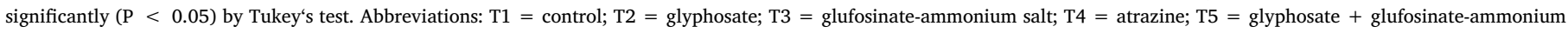
salt; $\mathrm{T} 6=$ glyphosate + atrazine; $\mathrm{T} 7=$ glufosinate-ammonium salt + atrazine; $\mathrm{T} 8=$ glyphosate + glufosinate-ammonium salt + atrazine .

(2015) found no significant differences when glyphosate (1440 g a.e. $\left.\mathrm{ha}^{-1}\right)$, two applications of glyphosate (1440 g a.e. ha ${ }^{-1}+1440 \mathrm{~g}$ a.e. $\left.\mathrm{ha}^{-1}\right)$, and glyphosate + atrazine $\left(1440 \mathrm{~g}\right.$ a.e. ha ${ }^{-1}+1500 \mathrm{~g}$ a.i. $\mathrm{ha}^{-1}$ ) were applied to corn. Various studies in the past have found that RR corn has a high tolerance and low phytotoxicity for the glyphosate herbicide (Albrecht et al., 2017; Nurse et al., 2006; Norsworthy and Frederick, 2005; Armel et al., 2003).

The evaluations of the height insertion, diameter of the stalk, and prolificacy index of the RR2/LL corn performed in R6 were not significantly different across all the treatments in both agricultural years (Fig. 4A, B, and C). These results are similar to those of previous studies (Osório et al., 2015; Vieira Júnior et al., 2015) where the type of herbicide used did not result in a significant difference in the insertion height of the first cob. Thus, the treatments applied in this study do not have deleterious effects toward these components in the corn with the cp4-epsps and pat genes. Highlighting still that the smallest initial height of T8 in V12 (Fig. 2 A), did not appear as a tendency for the variable of insertion height.

We found that in $2012 / 2013$, the weight of 100 seeds was much greater with the application of the T8 treatment than with the T1 (witness) (Fig. 5 A). However, even without presenting a statistical difference for the 2012/13 corn yield (Fig. 5 B). The T8 it was shown less yield, despite the greater weight of grains than that obtained with the other treatments. Decreased yield may have been the result of less rows of grains per cob and/or less grains per row, which are corn production components that are directly related to the yield of the corn culture (Fancelli and Dourado Neto, 2004; Fornasieri Filho, 2007).

In season 2013/14 the weight of 100 seeds did not differ across the treatments (Fig. $5 \mathrm{~A}$ ), there was a significant reduction in the yield of corn in the T8 treatment compared to that in the other treatments 
A

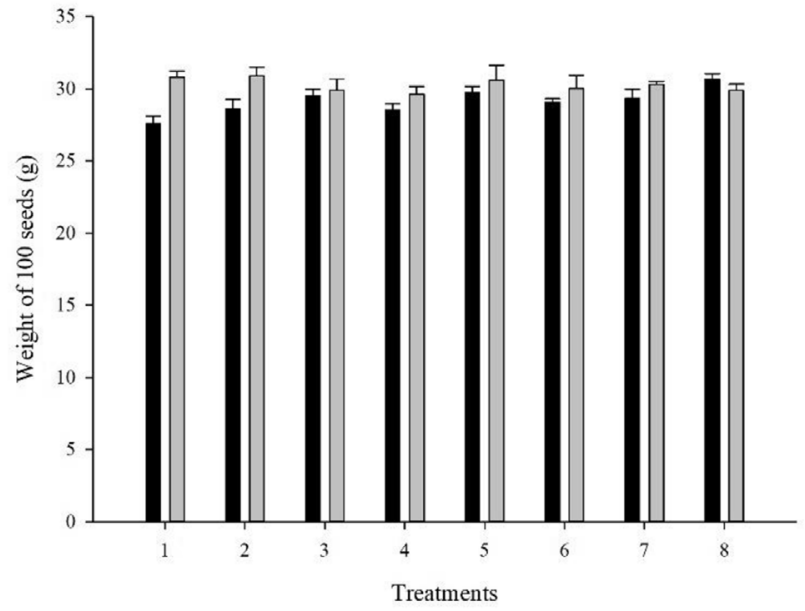

B

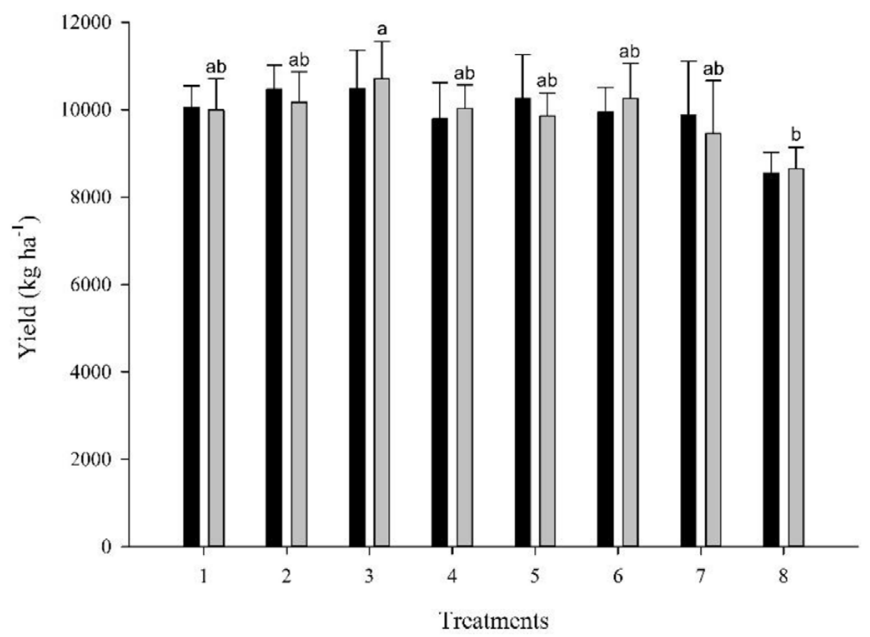

Season 2013/2014

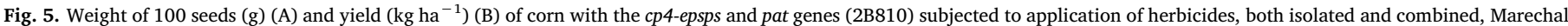

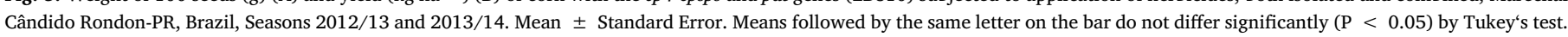

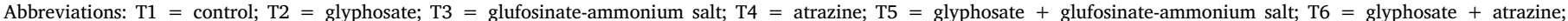
$\mathrm{T} 7$ = glufosinate-ammonium salt + atrazine; $\mathrm{T} 8=$ glyphosate + glufosinate-ammonium salt + atrazine .

A

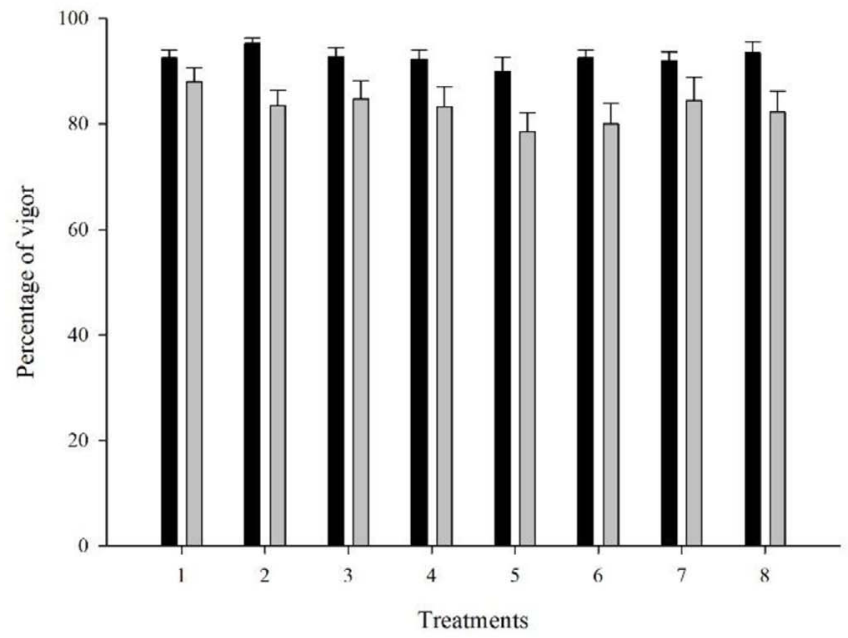

B

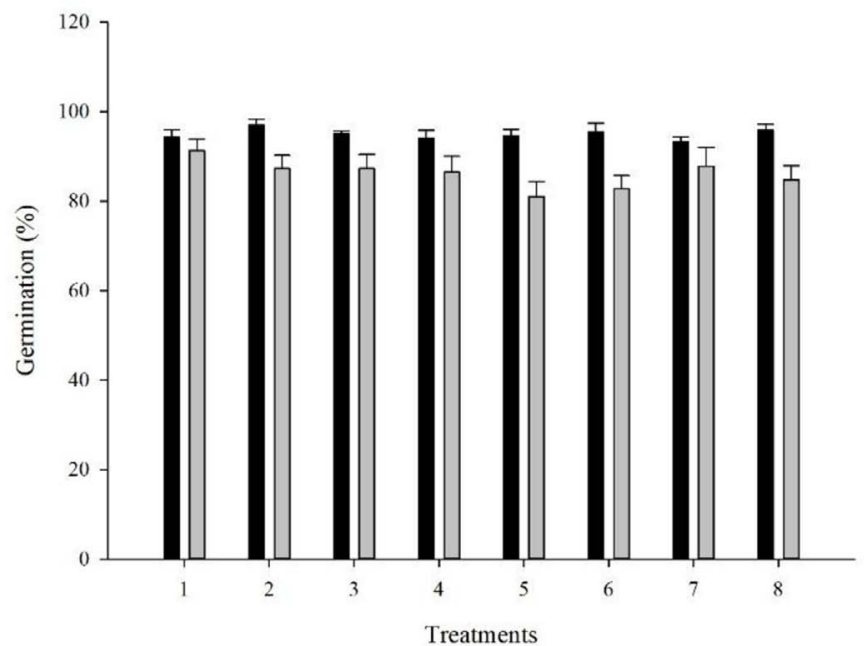

Season $2013 / 2014$

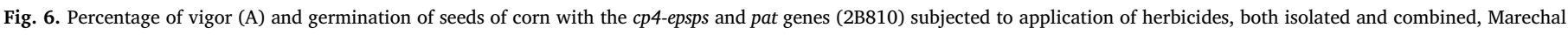

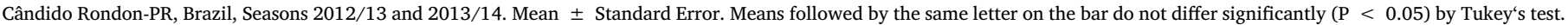

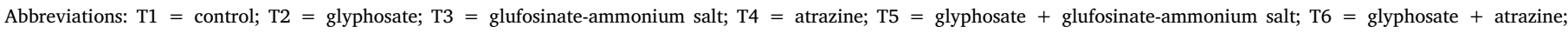
$\mathrm{T} 7$ = glufosinate-ammonium salt + atrazine; $\mathrm{T} 8=$ glyphosate + glufosinate-ammonium salt + atrazine .

(Fig. 5B). Correia and Santos (2013) also observed a decline in corn yield when they used a combined nicosulfuron + atrazine herbicide application. However, unlike in our study, Armel et al. (2008) did not observe a decrease in the LL corn yield with aglufosinate + mesotrione herbicide combination.

According to Norris et al. (2001), combining herbicides has beneficial effects, in that it reduces application costs and, in some cases, widens the range of controlled weeds. However, the combination of 
herbicides with different action mechanisms, even in cultures that are tolerant, can compromise the culture and cause damage as they interfere with more than one metabolic route within the plant. This was evident in the corn with the cp4-epsps and pat genes in the 2013/14 Season (Fig. 5B) in which the mixture of glyphosate + glufosinateammonium + atrazine (T8) reduced corn yield.

In the first germination test score (\% of vigor) and for germination in general, there was no significant difference across treatments, demonstrating that the herbicides did not alter the seeds' germination potential (Fig. 6). In glufosinate-tolerant rice, the strength and germination of the seeds submitted to the glufosinate application did not decrease (Webster et al., 2003). Moreover, in glufosinate-tolerant soybean, applications of the herbicide increased the protein content and diminished the oil and linoleic acid content of the seeds (Reddy et al., 2011).

In general, the application of single herbicides (T2, T3, and T4) did not negatively affect the RR2/LL corn culture; this finding is supported in many previous studies (Vieira Júnior et al., 2015; Armel et al., 2008).

The combination of two herbicides is useful when there may be weeds present that are resistant to a particular herbicide (Norris et al., 2001). In this study, we found that a combination of two herbicides decreased the initial height of the corn; however, the final height and yield were not affected. Thus, a post-emergent application of a combination of glyphosate + glufosinate-ammonium (T5), glyphosate + atrazine (T6), or glufosinate-ammonium + atrazine (T7) did not result in yield losses of corn cultures.

However, the combination of all three herbicides, glyphosate + glufosinate-ammonium + atrazine (T8), requires greater attention as it may cause damage to the corn yield, as we observed in the 2013/14 Season (Fig. 5B).

\section{Acknowledgements}

We thank the Federal University of Paraná for the support and development of research.

\section{References}

Albrecht, A.J.P., Albrecht, L.P., Krenchinski, F.H., Wobeto, K.S., Mattiuzzi, M.D., Eckert, C.T., Carbonari, C.A., 2017. Assessment of Roundup Ready 2 (RR2) corn subjected to application of isolated and associated herbicides. Aust. J. Crop Sci. 11, 974-981.

Anvisa, 2016. G05.1 - Glufosinato - sal de amônio. http://portal.anvisa.gov.br, Accessed date: 13 March 2016.

Armel, G.R., Richardson, R.J., Wilson, H.P., Hines, T.E., 2008. Mesotrione and glufosinate in glufosinate-resistant corn. Weed Technol. 22, 591-596.

Armel, G.R., Wilson, H.P., Richardson, R.J., Hines, T.E., 2003. Mesotrione alone and in mixtures with glyphosate in glyphosate-resistant corn (Zea mays). Weed Technol. 17, 680-685.
Bayer Crop Science, 2016. Liberty Link. http://www.bayercropscience.com.br, Accessed date: 13 March 2016

Brasil, 2009. Ministério da Agricultura, Pecuária e Abastecimento. Regras para análise de sementes. Secretaria de Defesa Agropecuária, Brasília 398 p.

Conab, 2016. Acompanhamento da safra brasileira: Safra 2015/16 Nono Levantamento, vol. 3. pp. 1-174.

Correia, N.M., Santos, E.A., 2013. Teores foliares de macro e micronutrientes em milho tolerante ao glyphosate submetido à herbicidas. Semina Ciências Agrárias 34, 3165-3171.

CTNBio, 2017. Aprovações Comerciais - CTNBio. http://ctnbio.mcti.gov.br/liberacaocomercial\#/liberacao-comercial/consultar-processo, Accessed date: 9 June 2016.

Dan, H.A., Barroso, A.L.L., Dan, L.G.M., Finotti, T.R., Feldkircher, C., Santos, V.S., 2010 Controle de plantas daninhas na cultura do milho por meio de herbicidas aplicados em pré-emergência. Pesqui. Agropecuária Trop. 40, 388-393.

Embrapa, 2013. Sistema brasileiro de classificação de solos, third ed. Brasília, 353 p.

Everman, W.J., Mayhew, C.R., Burton, J.D., York, A.C., Wilcut, J.W., 2009. Absorption, translocation, and metabolism of 14C-glufosinate in glufosinate-resistant corn, goosegrass (Eleusine indica), large crabgrass (Digitaria sanguinalis), and sicklepod (Senna obtusifolia). Weed Sci. 57, 1-5.

Falker, 2009. Medidor Eletrônico de Teor de Clorofila - clorofiLOG. http://www.falker. com.br/Produto.php?id=4, Accessed date: 12 June 2016.

Fancelli, A.L., Dourado Neto, D., 2000. Ecofisiologia e fenologia. Pages 21-54 in Fancelli AL, Dourado Neto D Produção de milho. Agropecuária, Guaiba.

Fancelli, A., Dourado Neto, D., 2004. Produção de milho, second ed. Livro ceres, Piracicaba 360 p.

Fornasieri Filho, D., 2007. Manual da cultura do milho. FUNEP, Jaboticabal 576 p.

Iapar, 1987. Cartas Climáticas Básicas Do Estado Do Paraná. Londrina, 35 p.

Karam, D., Gama, J.C.M., 2008. Radiografia dos herbicidas. Cultiv. Gd. Cult. 63, 24-27.

Monsanto, 2016. Produtos - Milho Roundup Ready. http://www.monsanto.com/global/ br/produtos/pages/protecao-de-cultivos.aspx, Accessed date: 13 June 2016.

Norris, J.L., Shaw, D.R., Snipes, C.E., 2001. Weed control from herbicide combinations with three formulations of glyphosate. Weed Technol. 15, 552-558.

Norsworthy, J.K., Frederick, J.R., 2005. Integrated weed management strategies for maize (Zea mays) production on the southeastern coastal plains of North America Crop Prot. 24, 119-126.

Nurse, R.E., Swanton, C.J., Tardif, F., Sikkema, P.H., 2006. Weed control and yield are improved when glyphosate is preceded by a residual herbicide in glyphosate-tolerant maize (Zea mays). Crop Prot. 25, 1174-1179.

Osório, C.W., Bardiviesso, D.M., de Souza, E.I.S., da Costa Leite, R., Leal, A.J.F., de Souza, H.M., 2015. Milho RR submetido a diferentes manejos de herbicidas e adubação foliar. Nativa 3, 78-82.

Pimentel-Gomes, F., Garcia, C.H., 2002. Estatística aplicada a experimentos agronômicos e florestais: exposição com exemplos e orientações para uso de aplicativos. FEALQ, Piracicaba 309 p.

Reddy, K.N., Bellaloui, N., Zablotowicz, R.M., 2009. Physiological and yield response of transgenic and non-transgenic corn to glyphosate. In: Abstracts of Papers of the American Chemical Society, pp. 374374.

Reddy, K.N., Zablotowicz, R.M., Bellaloui, N., Ding, W., 2011. Glufosinate effects on nitrogen nutrition, growth, yield, and seed composition in glufosinate-resistant and glufosinate-sensitive soybean. Int. J. Agron. 2011, 1-9.

Ritchie, S.W., Hanway, J.J., Benson, G.O., 2001. Como a planta de milho se desenvolve. Inf. Potafós 15, 1-20.

Vieira Júnior, N.S., Jakelaitis, A., Cardoso, I.S., Rezende, P.N., Moraes, N.C., Araújo, V.T., Tavares, C.J., 2015. Associação de herbicidas aplicados em pós-emergência na cultura do milho. Gl. Sci. Technol. 08, 1-8.

Webster, E.P., Lanclos, D.Y., Zhang, W., 2003. Influence of glufosinate on seed weight, Seed germination, and seedling vigor of glufosinate-resistant rice. Weed Technol. 17, 51-54. 